\title{
PENAPISAN (SKRINING) AKTIVITAS ANTIBAKTERI BEBERAPA EKSTRAK SPONS DARI TELUK MANADO
}

\author{
(Antibacterial Activities Screening of Some Sponge Extracts From Manado Bay)
}

\section{Edgar Nowin ${ }^{1 *}$, Veibe Warouw ${ }^{1}$, Joice R. T. S. L. Rimper ${ }^{1}$, James J. H. Paulus ${ }^{1}$, Henneke Pangkey ${ }^{2}$, Deiske A. Sumilat ${ }^{1}$}

1. Program Studi Ilmu Kelautan, Fakultas Perikanan dan Ilmu Kelautan, Universitas Sam Ratulangi, Manado.

2. Program Studi Budidaya Perairan, Fakultas Perikanan dan Ilmu Kelautan, Universitas Sam Ratulangi, Manado.

*e-mail : edgarakay@gmail.com

Sponges are one of the most prospective marine biotas as a source of natural materials such as peptides, terpenoids, steroids, acetogenins, alkaloids, cyclic halides, and other nitrogen compounds. These compounds have pharmacological activity such as antifouling, antitumor, antiinflammatory, antiviral, antibacterial, antifungal, and antimalarial. There were twelve sponges collected and have been extracted from Manado Gulf, North Sulawesi. Screening of the antibacterial activities have done by using a modified Kirby and Bauer method. The extraction of samples conducted using ethanol solvent then evaporated with rotary vacuum evaporator, 9.442 grams of sample extracts were gained. The twelve screened extracts obtained were $10.6 \mathrm{~mm}$ (extract 1), $7.4 \mathrm{~mm}$ (extract 4) and $(10.6 \mathrm{~mm}$ ) of extract 9 which had antibacterial activity against Bacillus megaterium bacteria on bacterial media Escherichia coli only extract 1 (8,9 mm) which could inhibit the bacterial growth. Positive controls used as comparison had much greater activity against $B$. megaterium and $E$. coli antibacterial components present in sponge extracts collected from Manado Bay are classified as medium/moderate compounds.

Keywords: Sponges, Antibacterial, Bacillus megaterium, Escherichia coli

Spons merupakan salah satu biota laut yang sangat prospektif sebagai sumber senyawa bahan-bahan alami seperti peptida, terpenoid, steroid, asetogenin, alkaloid, halida siklik, dan senyawa nitrogen lainnya. Senyawa-senyawa ini memiliki aktivitas farmakologis seperti antifouling, antitumor, antiinflamasi, antivirus, antibakteri, antijamur, antimalaria. Telah diekstrak dua belas spons yang dikoleksi dari Teluk Manado, Sulawesi Utara. Pengujian aktivitas antibakteri dalam penelitian ini menggunakan metode Kirby-Bauer yang dimodifikasi. Hasil yang diperoleh dalam penelitian ini dari koleksi beberapa ekstrak spons sebanyak 9,442 gram melalui proses maserasi dengan pelarut etanol dan evaporasi. Kedua belas ekstrak yang diskrining didapatkan 10,6 mm (ekstrak 1), 7,4 mm (ekstrak 4) dan (10,6 mm) ekstrak 9 yang memiliki aktivitas antibakteri terhadap bakteri Bacillus megaterium sedangkan pada media bakteri Escherichia coli hanya ekstrak $1(8,9 \mathrm{~mm})$ yang dapat menghambat pertumbuhan bakteri. Kontrol positif sebagai pembanding memiliki aktivitas yang jauh lebih besar terhadap bakteri $B$. megaterium dan $E$. coli sehingga senyawa antibakteri yang terdapat dalam ekstrak spons yang dikoleksi dari Teluk Manado digolongkan sebagai senyawa yang bersifat sedang/moderate.

Kata kunci: Spons, Antibakteri, Bacillus megaterium, Escherichia coli

\section{PENDAHULUAN}

Perairan laut Indonesia merupakan sumber senyawa bioaktif yang sangat melimpah untuk dikembangkan sebagai senyawa pemandu (lead compound) dalam sintesis obat-obatan baru (Lee et al., 2001; Nursid et al., 2006). Escherichia coli merupakan contoh bakteri yang resisten terhadap beberapa jenis antibiotik. Multi Drugs Resistance (MDR) adalah istilah bagi suatu bakteri yang resisten terhadap lebih dari 3 jenis antibiotik. Bacillus megaterium adalah suatu organisme yang tidak berbentuk filament, bakteri Gram positif, berbentuk batang, menghasilkan endospora, katalase positif, aerobik, nitrit negatif dan VP negatif (Hadieotomo, 1985). 
Antibakteri adalah zat atau senyawa yang dapat mengganggu pertumbuhan bahkan dapat mematikan bakteri dengan cara merusak metabolisme mikroba (Schunack et al., 1990; Madigan, 2005).

Spons saat ini telah menjadi perhatian utama dalam berbagai riset mengenai senyawa bioaktif antibakteri yang dikandungnya (Undap et al., 2017; Ngantung et al., 2016; Wewengkang et al., 2014; Bara, 2007). Senyawasenyawa ini memiliki aktivitas farmakologis seperti antifouling, antitumor, antiinflamasi, antivirus, antibakteri, antijamur, antimalarial. Beberapa tahun terakhir telah ditemukan senyawa-senyawa dari spons (Bara, 2007; Rompas, 2011; Rahman et al., 2014; Blunt et al., 2015). Spons memiliki potensi senyawa bioaktif terbesar di antara invertebrata laut lainnya (Ginting et al., 2010). Berbagai substansi bioaktif telah berhasil ditemukan seperti antibakteri dari spons yang dapat menghambat pertumbuhan bahkan membunuh bakteri (Mangindaan et al., 1997). Tujuan dari penelitian ini untuk mendapatkan beberapa ekstrak spons dan menganalisis aktivitas antibakteri ekstrak spons dari Teluk Manado. Sumilat (2017) telah meneliti bioaktivitas spons laut yang berasal dari salah satu Perairan di Teluk manado.

\section{METODE PENELITIAN}

\section{Lokasi Pengambilan Sampel}

Pengambilan sampel dilakukan di Teluk Manado (Gambar 1), ekstraksi dan skrining antibakteri dilakukan di Laboratorium Biologi Molekuler dan Farmasetika Fakultas Perikanan dan IImu Kelautan Universitas Sam Ratulangi Manado.
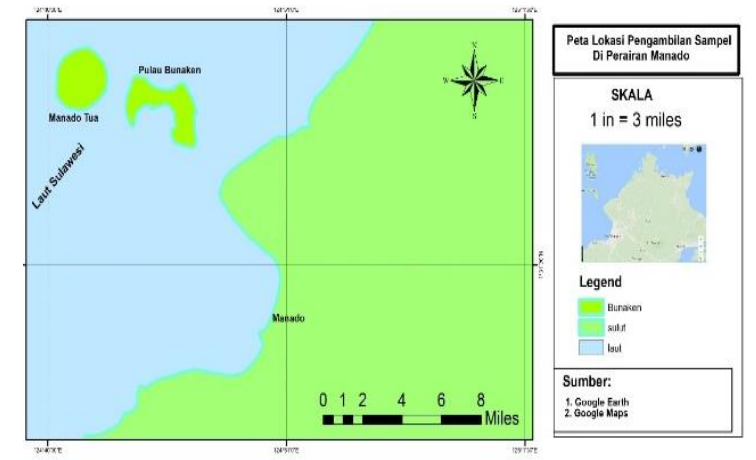

Gambar 1. Peta Pengambilan Sampel

\section{Sterilisasi Alat dan Media}

Alat-alat yang digunakan dalam penelitian ini seperti cawan petri, tabung reaksi, scalpel, gunting dan pinset dicuci bersih, dikeringkan, dibungkus kemudian disterilkan dalam oven pada suhu $150^{\circ} \mathrm{C}$ selama \pm 2 jam (sterilisasi kering). Media untuk pertumbuhan mikroorganisme disterilisasi dalam autoklaf pada suhu $121^{\circ} \mathrm{C}$ selama 15 menit (sterilisasi basah).

\section{Pembuatan Media B1 dan Preparasi Bakteri}

\section{Media Cair B1}

Pembuatan media cair B1 untuk kultur bakteri (B. Megaterium dan E.coli) dengan menggunakan bahan pepton 0,5 gram, ekstrak daging (meat extract) 0,3 gram, natrium klorida $(\mathrm{NaCl}) 0,3$ gram. Bahan yang telah ditimbang dimasukkan ke dalam erlenmeyer yang sudah berisikan aquades $/ \mathrm{dH}_{2} \mathrm{O}$ sebanyak $100 \mathrm{ml}$, kemudian dibuat homogen lalu ditutup dan dibungkus menggunakan aluminium foil dan disterilkan menggunakan autoklaf pada suhu $121^{\circ} \mathrm{C}$ selama \pm 15 menit.

\section{Media Padat B1}

Pembuatan media padat menggunakan bahan pepton 1 gram, daging (meat extract) 0,6 gram, natrium klorida ( $\mathrm{NaCl})$ 0,6 gram, agar 6 gram. Bahan yang sudah ditimbang dimasukkan ke dalam erlenmeyer yang 
sudah berisi aquades aquades $/ \mathrm{dH}_{2} \mathrm{O}$ sebanyak $200 \mathrm{ml}$. Media dibuat sebanyak dua untuk kedua bakteri dan di disterilkan menggunakan autoklaf pada suhu $121^{\circ} \mathrm{C}$ selama \pm 15 menit.

\section{Pembuatan Konsentrasi Sampel}

Penelitian ini menggunakan konsentrasi $100 \mathrm{mg} / \mathrm{ml}$ dan diencerkan dengan pelarut metanol 100\% menggunakan mikropipet.

\section{Skrining Aktivitas Antibakteri Ekstrak Spons}

Skrining antibakteri beberapa ekstrak spons pada penelitian ini menggunakan konsentrasi dari tiap ekstrak kasar sampel spons sebanyak $100 \mathrm{mg} / \mathrm{ml}$ dan diambil $50 \mu \mathrm{l}$ menggunakan mikropipet dan ditotolkan pada setiap kertas cakram dan dimasukkan ke dalam wadah steril yang telah diberi tanda (Wikler et al., 2009). Setelah itu kertas cakram dikeluarkan satu persatu dari wadah dan diletakkan di atas media padat B1. Skrining antibakteri yang dilakukan pada penelitian ini dengan menggunakan metode (disc diffusion Kirby and Bauer). Metode ini dikembangkan sejak tahun 1961. Metode ini banyak digunakan untuk menguji sensitivitas suatu antibiotik terhadap bakteri tertentu (Fall, 2011).

\section{Pengamatan dan Pengukuran Zona Hambat}

Setelah pentotolan pada kertas cakram yang telah diletakkan pada media padat, kemudian aktivitas antibakteri dari masing-masing ekstrak spons diukur diameter zona hambat yang terbentuk di sekitar ekstrak spons dengan menggunakan penggaris dalam satuan $(\mathrm{mm})$ dan diamati zona hambat ekstrak spons pada bakteri $E$. coli dan $B$. megaterium. Pengamatan dilakukan setelah $1 \times 24$ Jam untuk melihat sifat antibakteri dari tiap ekstrak spons.

\section{HASIL DAN PEMBAHASAN}

Identifikasi morfologi dengan cara membandingkan warna, bentuk, dan ciri dari dua belas spons yang digunakan dalam penelitian ini berdasarkan panduan dari Colin dan Arneson (1995); Hooper dan Van Soest (2002). Setelah pengamatan selama $1 \mathrm{x}$ 24 masa inkubasi dengan 3 kali pengulangan didapatkan aktivitas antibakteri dari ekstrak 1, 4, dan 9 terhadap bakteri $B$. megaterium sedangkan pada bakteri $E$. coli hanya ekstrak spons 1 yang menunjukan aktivitas antibakteri (Gambar 2 dan 3).

Spons yang didapatkan seperti Liosina sp. dan Clathria sp. telah diteliti sebelumnya oleh Setyowati et al., (2007) mendapatkan bioaktivitas antimikroba yang diujikan pada bakteri E. coli, S. aureus dan C. albicans. Spons Halichondria sp. memiliki aktivitas antikanker seperti yang dinyatakan Wirmandiyanthi (2013) bahwa senyawa yang diisolasi dari spons Halichondria okadai terbukti aktif melawan leukemia. Leucetta sp. yang berasal dari Perairan Pulau Menjangan Bali Barat yang diteliti oleh Martiningsih (2013) mengandung senyawa alkaloid yang memberikan pengaruh sitotoksik. Trianto et al., (2004) menganalisa dari fraksi Isis sp. memiliki aktivitas Plakortis sp. yang di koleksi dari Perairan Pulau Bunaken telah di teliti oleh Pasodung et al., (2017), terbukti senyawa bioaktivitas spons Plakortis sp. memiliki potensi untuk dikembangkan sebagai obat antibakteri. 

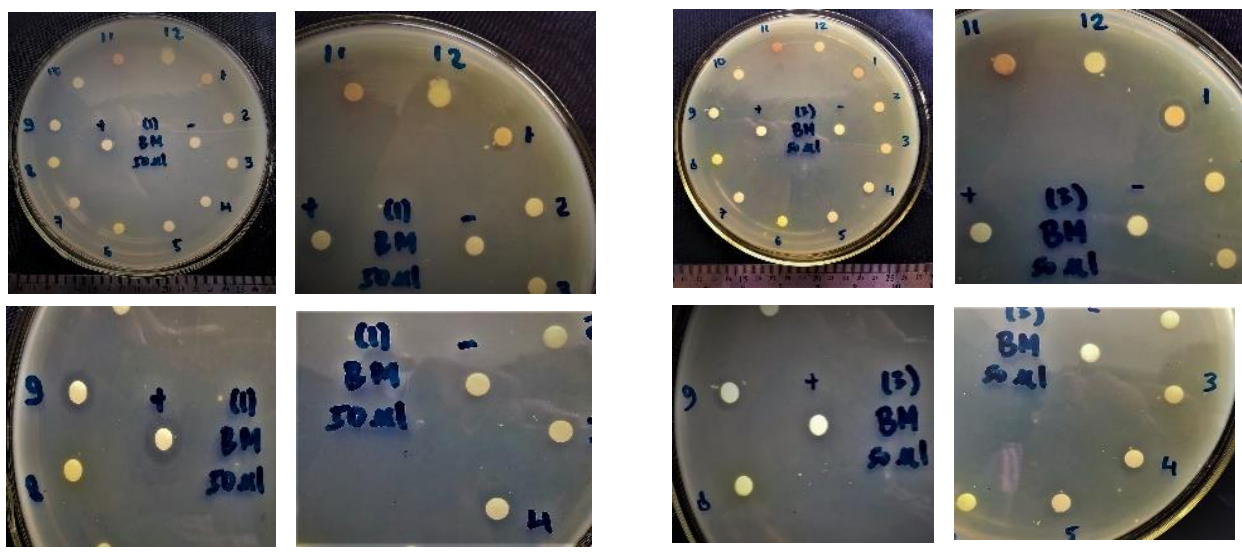

Ulangan 1

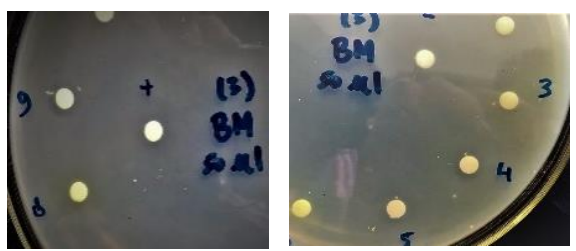

Ulangan 3
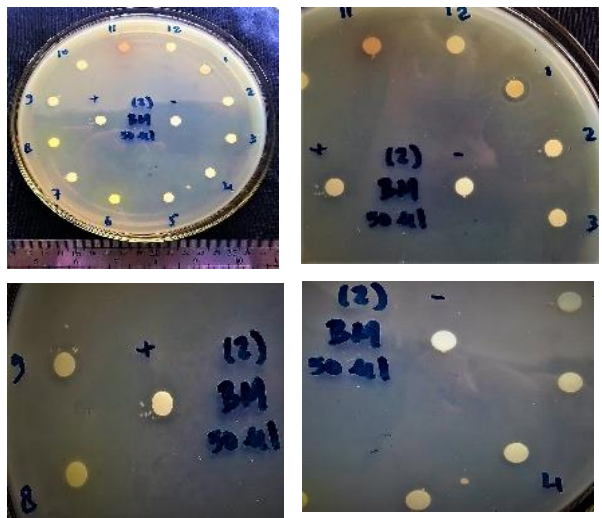

Ulangan 2

Gambar 2. Aktivitas antibakteri beberapa ekstrak spons pada media bakteri Bacillus megaterium (Dokumentasi pribadi, 2018).
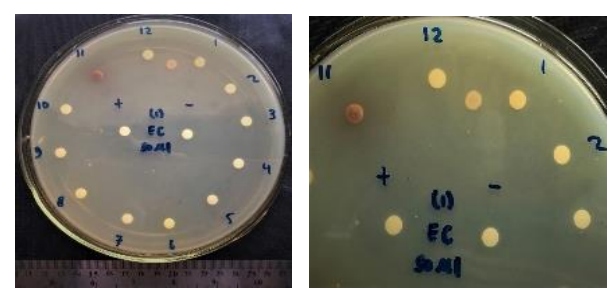

Ulangan 1
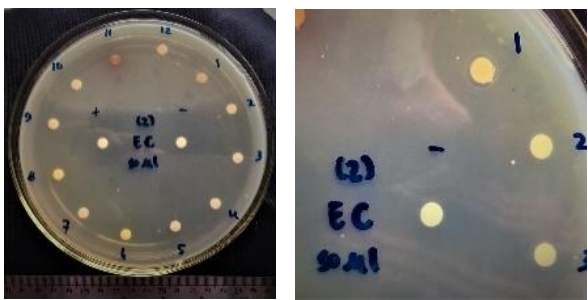

Ulangan 2

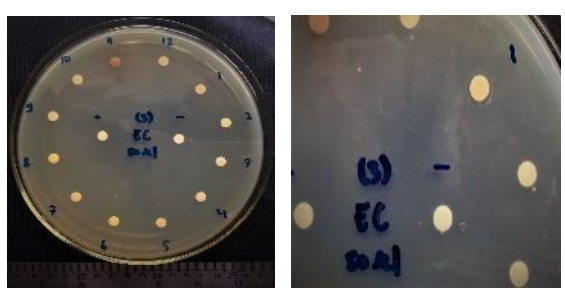

Ulangan 3

Gambar 3. Aktivitas antibakteri beberapa ekstrak spons pada media bakteri Escherichia coli (Dokumentasi pribadi, 2018). 
Tabel 1. Hasil pengukuran diameter zona hambat dari beberapa ekstrak spons terhadap bakteri Bacillus megaterium

\begin{tabular}{|c|c|c|c|c|c|}
\hline \multirow[b]{2}{*}{ Ekstrak spons } & \multirow[b]{2}{*}{$\begin{array}{l}\text { Berat } \\
\text { kering } \\
\text { (gram) }\end{array}$} & \multicolumn{4}{|c|}{$\begin{array}{l}\text { Bacillus megaterium } \\
\text { Zona hambat }(\mathrm{mm})\end{array}$} \\
\hline & & Ulangan 1 & Ulangan 2 & Ulangan 3 & Rerata \\
\hline 1 & 0,509 & 10,7 & 10,5 & 10,7 & 10,6 \\
\hline 2 & 2,644 & - & - & - & - \\
\hline 3 & 0,240 & - & - & - & - \\
\hline 4 & 0,376 & 7,7 & 7 & 7,7 & 7,4 \\
\hline 5 & 1,164 & - & - & - & - \\
\hline 6 & 1,195 & - & - & - & - \\
\hline 7 & 0,377 & - & - & - & - \\
\hline 8 & 1,105 & - & - & - & - \\
\hline 9 & 0,874 & 11,2 & 10,2 & 10,5 & 10,6 \\
\hline 10 & 0,207 & - & - & - & - \\
\hline 11 & 0,271 & - & - & - & - \\
\hline 12 & 0,480 & - & - & - & - \\
\hline $\begin{array}{c}\text { Kloramfenikol } \\
(+)\end{array}$ & - & 14,5 & 12,2 & 12,7 & 13 \\
\hline Metanol (-) & - & - & - & - & - \\
\hline $\begin{array}{l}\text { Keterangan : } \\
\text { Kosentrasi kont } \\
\text { Diameter kertas } \\
\text { Daya serap ker } \\
\text { Banyaknya eks } \\
\text { Konsentrasi sar }\end{array}$ & $\begin{array}{l}\text { positif } \\
\text { kram } \\
\text { cakram } \\
\text { dalam I } \\
\text { el dalam }\end{array}$ & $\begin{array}{l}\text { as cakram } \\
\text { tas cakram }\end{array}$ & $\begin{array}{l}=250 \mathrm{mg} / \mathrm{m} \\
=6 \mathrm{~mm} \\
=100 \mu \mathrm{l} \\
=50 \mu \mathrm{l} \\
=100 \mathrm{ml} / \mathrm{mg}\end{array}$ & & \\
\hline
\end{tabular}

Melalui data yang ditampilkan pada Tabel 1 dan 2 menunjukan bahwa setelah dilakukan pengujian aktivitas antibakteri dari beberapa ekstrak spons terhadap bakteri uji $B$. megaterium dan $E$. coli maka didapatkan diameter zona hambat yang bervariasi. Dibandingkan dengan kontrol positif (kloramfenikol) bahwa senyawa dari ekstrak spons mempunyai zona hambat yang lebih rendah. Sedangkan pada media bakteri $E$. coli hanya ekstrak spons $1(8,9 \mathrm{~mm})$ yang memperlihatkan zona hambat. Kontrol positif sebagai pembanding memiliki aktivitas yang jauh lebih besar terhadap bakteri $E$. coli sehingga senyawa antibakteri yang terdapat dalam ekstrak spons yang dikoleksi dari Teluk Manado digolongkan sebagai senyawa yang bersifat sedang/moderate (Patel et al., 2014).

Skrining ekstrak spons pada penelitian ini menunjukan adanya aktivitas beberapa ekstrak spons yang berpotensi membunuh bakteri $B$. megaterium dan $E$. coli. 
Tabel 2. Hasil pengukuran diameter zona hambat dari beberapa ekstrak spons terhadap bakteri Escherichia coli

\begin{tabular}{|c|c|c|c|c|c|}
\hline \multirow[t]{2}{*}{ Ekstrak spons } & \multirow{2}{*}{$\begin{array}{l}\text { Berat } \\
\text { kering } \\
\text { (gram) }\end{array}$} & \multicolumn{4}{|c|}{$\begin{array}{c}\text { Escherichia coli } \\
\text { Zona hambat }(\mathrm{mm})\end{array}$} \\
\hline & & Ulangan 1 & Ulangan 2 & Ulangan 3 & Rerata \\
\hline 1 & 0,509 & 8,2 & 9,7 & 9 & 8,9 \\
\hline 2 & 2,644 & - & - & - & - \\
\hline 3 & 0,240 & - & - & - & - \\
\hline 4 & 0,376 & - & - & - & - \\
\hline 5 & 1,164 & - & - & - & - \\
\hline 6 & 1,195 & - & - & - & - \\
\hline 7 & 0,377 & - & - & - & - \\
\hline 8 & 1,105 & - & - & - & - \\
\hline 9 & 0,874 & - & - & - & - \\
\hline 10 & 0,207 & - & - & - & - \\
\hline 11 & 0,271 & - & - & - & - \\
\hline 12 & 0,480 & - & - & - & - \\
\hline $\begin{array}{c}\text { Kloramfenikol } \\
(+)\end{array}$ & - & 30,7 & 30,5 & 30,2 & 30,4 \\
\hline Metanol (-) & - & - & - & - & - \\
\hline $\begin{array}{l}\text { Keterangan : } \\
\text { Kosentrasi kon } \\
\text { Diameter kerta } \\
\text { Daya serap ker } \\
\text { Banyaknya eks } \\
\text { Konsetrasi sam }\end{array}$ & $\begin{array}{l}\text { positif } \\
\text { akram } \\
\text { cakram } \\
\text { k dalam } \\
\text { dalam }\end{array}$ & $\begin{array}{l}\text { tas cakram } \\
\text { tas cakram }\end{array}$ & $\begin{array}{l}=250 \mathrm{mg} / \mathrm{m} \\
=6 \mathrm{~mm} \\
=100 \mu \mathrm{l} \\
=50 \mu \mathrm{l} \\
=100 \mathrm{ml} / \mathrm{mg}\end{array}$ & & \\
\hline
\end{tabular}

Skrining ekstrak spons pada penelitian ini menunjukan adanya aktivitas beberapa ekstrak spons yang berpotensi membunuh bakteri $B$. megaterium dan $E$. coli. Pada penelitian ini tampak bahwa kloramfenikol lebih efisien dalam menghambat pertumbuhan bakteri $B$. megaterium dan $E$. coli. Hal ini dikarenakan tepatnya konsentrasi senyawa dalam obat tersebut, sedangkan kemampuan senyawa yang dihasilkan dari spons belum diketahui (Patel et al., 2014). Kloramfenikol digunakan dalam peneletian ini sebagai tolak ukur untuk menguji aktivitas antibakteri ekstrak spons.

Kontrol negatif berfungsi untuk memperlihatkan apakah media tercemar atau tidak. Kontrol negatif menunjukan perbedaan terhadap kontrol positif maupun ekstrak sampel uji. Dalam penelitian ini, kontrol negatif tidak menunjukan adanya zona hambat pada skrining antibakteri terhadap bakteri $B$. megaterium dan bakteri $E$. coli. 


\section{KESIMPULAN}

Beberapa ekstrak spons berhasil diperoleh sebanyak 9,442 gram melalui proses maserasi dengan pelarut etanol dan evaporasi. Ekstrak spons dari Teluk Manado memiliki aktivitas antibakteri terhadap pertumbuhan bakteri $B$. megaterium dengan diameter 10,6 mm (Ekstrak 1), 7,4 mm (Ekstrak 4), 10,6 mm (Ekstrak 9). Kemudian pada bakteri E. coli dengan diameter zona hambat $8,9 \mathrm{~mm}$ (Ekstrak 1).

\section{DAFTAR PUSTAKA}

Bara, R. 2007. Study metabolic rate and metabolism in the spons Haliclona oculata using different 13C labeled substrates. Thesis. Wageningen University, Netherlands. p 47.

Blunt, J. W., Copp, B., Keyzers, R., Munro, R. A., Prinsep, M. H. G. 2015. Marine natural products. Nat. Prod. Rep. $32 . \quad$ DOI 10.1039/c4np00144c. pp. 116211.

Colin, P.L., Arneson A.Ch.. 1995. Tropical Pacific Invertebrates : A Field Guide to the Marine Invertebrates Occurring on Tropical Pacific Coral Reefs, Seagrass Beds and Mangroves. Mybar Printing Inc. America. p 305.

Fall, 2011. Kirby-Bauer Procedure. Jackie Reynolds, Richland College. pp. 114-116.

Ginting, E. L., Warouw V., Suleman R. W. 2010. Aktivitas Antibakteri dari Ekstrak Kasar Bakteri yang Berasosiasi dengan Sponge Acanthostrongylophora Sp.. Jurnal Perikanan dan Kelautan Tropis. ISSN: 2302-6081. 6(3):160-163.
Hadioetomo, R.S. 1985. Mikrobiologi Dasar-dasar Praktik. Gramedia. Jakarta.

Hooper, J.N.A dan Van Soest, R.W.M. 2002. Systema Porifera. A Guide to the Classification of Sponges. K1uwer Academic Plenum. Publishers New York. p 1778.

Lee, K. Y., Lee, H. J., Lee, H. K. 2001. Microbial Symbiosis in Marine Sponges. The Journal of Microbiology. 39(4):254-264.

Madigan, M. 2005. Brock Biology of Microorganisme. London. p 753.

Mangindaan, R. E. P., Nainggolan I. G. S., Losung F. 1997. Anti Mikroba dari Sponge di Teluk Manado. Prosiding Seminar Nasional Hasil dalam Bidang Farmasi. ISBN: 979- 95406-0 (7):544-548.

Martiningsih, N. W. 2013. Skrining Awal Ekstrak Etil Asetat Spons Leucetta sp. Sebagai Antikanker dengan Metode Brine Shrimp Lethality Test (BSLT). Fakultas MIPA Universitas Pendidikan Ganesha. Jurusan Analis Kimia. 382 hal.

Ngantung, A.E.C., Bara, R., Sumilat, D.A. 2016. Uji Aktivitas Antibakteri dari Spons Dictyonella funicularis dan Phyllospongia lamellosa yang diambil pada Perairan Bunaken. Jurnal Pesisir dan Laut Tropis. ISSN: 2339-1537. 2(1):10-16.

Nursid, D., Marraskuranto, E. 2007. Aktivitas Sitotoksik, Induksi Apoptosis dan Ekspresi Gen p53 Fraksi Metanol Spons Petrosia nigricans terhadap Sel Tumor Hela. Jurnal Pascapanen dan 
Bioteknologi Kelautan dan Perikanan. 1(2):103-109.

Pasodung, A. 2017. Uji Aktivitas Antibakteri Spons Plakortis sp. yang dikoleksi dari Perairan Bunaken. Skripsi. Program Studi IImu Kelautan. Fakultas Perikanan dan IImu Kelautan Universitas Sam Ratulangi, Manado. 47 hal.

Patel, J. B., Cockerill, F. R., Alder, J., Bradford, P. A., Eliopoulos, G. M., Hardy, D. J., Hindler, J. A., Jenkins, $\quad$ s. G., Lewis, J. S., Miller, L A., Powell, M.,

Swenson J. M., Traczewski, M. M., Turnidge, J. D., Weinsten, M. P., Zimmer, B. L. 2014. Performance Standards for Antimicrobial Susceptibility Testing; Twenty-Fourth Informational Supplement. Vol. 34. Clinical and Laboratory Standards Institute.

Rahman, H. 2014. Isolasi, Identifikasi dan Uji Bioaktivitas Metabolit Sekunder Ekstrak Kloroform Spons Petrosia alfiani dari Kepulauan Barrang Lompo. Skripsi. FMIPA UNHAS, Makassar.

Rompas, R. 2011. Farmakognosi Laut (Sumber Baru Ekonomi Kelautan). Dewan Kelautan Indonesia, Jakarta.

Setyowati, P. E., Umar A. J., Sudarsono, Broto K., Rachmaniar R. 2007. Toksisitas dan Aktivitas AntiMikroba Ekstrak Etanol Bunga Karang dari Perairan Pulau Tabuhan Banyuwangi dan Pulau Menjangan Bali Barat. Fakultas Farmasi Universitas Gadjah Mada Yogyakarta.
Jurnal Perikanan. ISSN: 250250669 (2).

Schunack, W., Mayer, K., Haake, M. 1990. Senyawa Obat. Universitas Gadjah Mada . 894 hal.

Sumilat, A. D. 2017. Aktivitas Spons Laut Lamellodysidea herbacea dari Perairan Malalayang. Jurnal LPPM Bidang Sains dan Teknologi. ISSN: 2407-6074. 4(1):1-7.

Trianto, A., Has Y. Y., Ambariyanto A., Murwani R. Uji Toksisitas Ekstrak Gorgo Gorgonian Isis hippuris terhadap Nauplius Artemia salina. Universitas Diponegoro. Indonesia journal of Marine Science. ISSN: 2406-7598. 9 (2): 61-63.

Undap, N.I.J., Sumilat, D.A., Bara, R. 2017. Aktivitas Antibakteri Spons Agelas tubulata dan Phyllospongia sp. dari Perairan Pantai Malalayang Manado Terhadap Pertumbuhan Beberapa Strain Bakteri. Jurnal IImu dan Managemen Perairan. ISSN: 2337-5000. 5 (1).

Wewengkang, D.S., Sumilat, D.A., Rotinsulu, H. 2014. Karakterisasi dan Bioaktif Antibakteri Senyawa Spons Haliclona sp. dari Teluk Manado. Jurnal LPPM Bidang Sains dan Teknologi. ISSN: 24076074. 1(1):71-85.

Wikler, M. A., Cockeril F. R., Bush K., Dudley M. N., Eliopoulos J. M., Hardy D. J., Hecht D. W. 2009. Performance Standards for Antimicrobial Disk Susceptibility Tests: Approved Standard 10th Edition. Clinical and Laboratory Standards Institute. Pennsylvania, USA.

Wirmandiyanthi D. K., Manurung M., Swantara I. M. D. 2013. Uji 
Toksisitas dan Identifikasi Ekstrak Haliclona fascigera Terhadap Larva Artemia salina L. Jurnal Perikanan dan Kelautan. Program Magister Kimia Terapan, Universitas Udayana. Bali. ISSN: 2302-7274. 1. 